\title{
BEING ELDER IS NOT WORST: STUDI TENTANG PROYEKSI PEMUDA PADA DAN SAAT MENJADI LANSIA
}

\author{
Siti Zuliani ${ }^{1}$, Fathul Lubabin Nuqul ${ }^{2}$ \\ 1.2 Universitas Islam Negeri Maulana Malik Ibrahim Malang, Indonesia. \\ ${ }^{2}$ Corresponding author. lubabin_nuqul@uin-malang.ac.id
}

\begin{abstract}
The projection of becoming elderly is one of the things that young people rarely think about in facing the next phase. The purpose of this study was to analyze the projections of youth into the elderly, which include attitudes and readiness to care for the elderly, youth expectations when they become elderly, and the efforts made to face the elderly. The research involves 224 people, about 17-24 years of age. The gender distribution was 75 males and 149 females. Data collection using an open questionnaire. The analysis used is theme/categorization analysis and descriptive analysis. The results show that youth who care for the elderly are not necessarily ready to become elderly. Both prepared and unprepared, both groups of subjects hope to have a prosperous life, have financial independence, and have a happy family.
\end{abstract}

Keyword: Projection, Youth, Elderly

\begin{abstract}
ABSTRAK
Proyeksi menjadi lansia merupakan salah satu hal yang jarang dipikirkan pemuda dalam menghadapi fase selanjutnya. Tujuan penelitian ini adalah untuk menganalisis proyeksi pemuda menjadi lansia, yang meliputi, sikap dan kesiapan merawat lansia, harapan pemuda saat menjadi lansia, serta upaya yang dilakukan menghadapi masa lansia. Latar subyek penelitian adalah pemuda yang berjumlah 224 dengan tentang usia antara17-24 tahun. Distribusi jenis kelamin 75 orang laki-laki dan 149 orang perempuan. Pengambilan data menggunakan angket terbuka. Analisis yang digunakan yaitu analisis tema/kategorisasi dan analisis deskriptif. Hasilnya menunjukkan bahwa pemuda yang yakin dalam merawat lansia belum tentu siap untuk menjadi lansia. Baik subjek yang siap menghadapi lansia maupun yang bukan, sama-sama mempunyai harapan mendapatkan hidup yang sejahtera, mempunyai kemandirian finansial dan keluarga yang Bahagia.
\end{abstract}

Kata Kunci: proyeksi, pemuda, lansia,

\section{LATAR BELAKANG}

Menjadi tua adalah sebuah kepastian, namun tidak semua orang siap menghadapi masa lanjut usia. Kesiapan seseorang menghadapi masa tua merupakan hal yang penting untuk dilalui dengan Bahagia meskipun hal ini bukan sesuatu yang mudah. Konflik anak dan orang tua atau anak dengan keluarga yang lain terkait dengan hak asuh lansia sering terjadi. Salah peristiwa yang viral tentang dikirimkannya seorang lansia ke panti jompo oleh anaknya sendiri, (suara.com, 2021). Peristiwa yang lain adalah lansia yang ditelantarkan hingga tidak terurus dipinggir jalan, (Solopos.com, 2021). Kedua peristiwa ini memberikan pesan bahwa menjadi lanjut usia hal yang sulit sehingga dibutuhkan kesiapan sedari dini.

Fase lansia sering terabaikan bagi pemuda.Data statistik menunjukkan bahwa dari tahun ke tahun angka lansia terus meningkat. Mulai tahun 2017 sampai tahun 2050 diperkirakan populasi penduduk 
lansia usia 60 ke atas berkisar lebih dari $7 \%$ populasi. Populasi lansia pada tahun 2017 sejumlah 862 juta orang, dua kali lipat lebih banyak dari pada tahun 1980 dengan angka 382 juta orang. Angka peningkatan ini diperkirakan pada tahun 2050 akan menjadi 2,1 miliar lansia di seluruh dunia. Sedangkan keberadaan lansia di Indonesia meningkat sekitar dua kali lipat selama kurun waktu lima dekade (1971-2019). Pada tahun 2019, persentase lansia mencapai 9,6\% atau sekitar 25,64 juta orang. Kondisi sekarang menunjukkan bahwa Indonesia menjadi negara dengan struktur penduduk tua (ageing population) jika sudah berada lebih dari $10 \%$ (Nugroho, 2020). Kondisi bertambahnya usia dan disertai penurunan daya tahan fisik bisa menimbulkan berbagai permasalahan kesehatan. Penurunan fungsi organ tubuh, keterbatasan fisik maupun mental menjadi permasalahan jika tidak dapat ditangani oleh diri sendiri sehingga lansia menggantungkan diri mereka kepada keluarga untuk dirawat(Wiyono et al., 2008; Yuhono, 2017). Pada pandemi covid 19 lansia menjadi perhatian karena kerentanan resiko terpapar. Catatan menunjukkakn pada usia 46 sampai dengan 59 , jumlah kematian yang terjadi mencapai 6,1 persen. Sementara kematian diatas usia 60 tahun sebanyak 14,67 persen.(Indarwati, 2020)

Kondisi ini membuat keluarga harus meluangkan waktu dan tenaga untuk menangani lansia yang tidak mampu secara mandiri. Lansia adalah masa dengan segala penyesuaian, mulai dari penyesuaian dengan penurunan fisik, penurunan penghasilan, penyesuaian perubahan status sosial dan penyesuaian akan kehilangan pasangan (Yuhono, 2017). Untuk mampu melakukan penyesuaian ini dibutuhkan upaya belajar dan kesiapan yang relative lama, karena lansia merupakan masa krisis berpotensi menjadi masalah di berbagai negara (Kaplan, 2011) . Beberapa negara memberikan porsi penyiapan anak muda untuk menjadi lansia sejak dini. Misal Gilles (n.d) mengemukakan tentang konsep inter-generasi, sebuah pola edukasi atau intervensi yang berisi tentang kegiatan bersama antara anak muda dengan lansia yang bertujuan untuk memberikan saling pengertian dan saling belajar tentang kehidupan masing-masing. Program ini banyak dilakukan di negara maju guna memudahkan perawatan dan peningkatan kesejahteraan lansia.

Lansia merupakan orang dewasa yang memiliki usia lebih dari 60 tahun (Karomah, 2015). Definisi lansia menurut undangundang kesehatan no 23 tahun 1992 pasal 19 ayat 1 yang berbunyi manusia usia lanjut merupakan seseorang yang karena usianya mengalami perubahan biologis, fisik, sikap, perubahan akan memberikan pengaruh pada keseluruhan aspek kehidupan termasuk kesehatan (Supriani et al., 2011). Menurut Harlock, dalam (Hurlock, 1991) menyatakan bahwa masa usia lanjut terdiri dari dua tahap yaitu masa usia lanjut awal yang berkisar antara 60 tahun sampai 70 tahun dan masa usia lanjut ditandai dengan dari usia 70 tahun sampai akhir kehidupan seseorang. Selain itu, menurut UU No 13 tahun 1998 menyatakan bahwa batasan usia lanjut yaitu seseorang yang telah mencapai usia lanjut 60 ke atas. (Misnaniarti, 2017)

Penelitian tentang lansia dalam tataran psikologi lebih banyak dilakukan terkait tentang pengujian kualitas dan kemampuan mental lansia serta sikap individu pada lansia atau ageism. Lansia banyak dianggap memiliki penurunan kualitas kognitif, kontrol emosi dan gerak fisik (Afrizal, 2018). penelitian juga menunjukkan bahwa lansia diharapkan mempunyai kesiapan untuk di tinggal 
pasangan (Afrizal, 2018; Ekowati, 2011) dan menghadapi kematian (Afrizal, 2018). Penelitian tentang ageism juga banyak dilakukan. Misalnya pengaruh populasi lansia pada tatanan masyarakat dan persepsi anak muda terhadap keberadaan lansia di Indonesia (Nugroho, 2020) menunjukkan bahwa masyarakat mempunyai prasangka pada lansia, dan menganggap lansia dengan penuh kelemahan. (Afrizal, 2018; Yuhono, 2017). Dalam konteks pandemi Covid 19, manusia usia lanjut di nilai mempunya banyak kerentanan (Indarwati, 2020; Siagian, 2020).

Penelitian tentang kesiapan pemuda untuk menjadi lansia belum banyak dikaji. Kesiapan pemuda menjadi lansia penting karena memberikan dampak pada Negara.

Selain itu, proyeksi yang dipersiapkan memudahkan pemuda untuk tidak bergantung pada orang lain dimasa tua. Berdasarkan paparan diatas penelitian ini bertujuan melakukan eksplorasi sikap pemuda pada lansia, harapan saat menjadi lansia serta upaya menghadapi masa lanjut usia.

\section{METODE PENELITIAN}

Guna menjawab rumusan masalah dan mencapai tujuan penelitian, dalam penelitian ini menggunakan pendekatan Mixed method, yaitu pendekatan gabungan kualitatif dengan metode naratif serta kuantitatif dengan menggunakan pendekatan deskriptif.

\section{SUBJEK PENELITIAN}

Pada penelitian sampel sebanyak 224 orang antara17-24 tahun. Distribusi jenis kelamin 75 orang laki-laki dan 149 orang perempuan. Pengambilan sampel menggunakan teknik pengambilan sampel yaitu non-probability sampling. Teknik ini merupakan sebuah model pengambilan sampel yang disengaja atau faktor lain seperti telah ditentukan oleh peneliti sebelumnya.

\section{PENGAMBILAN DATA}

Metode pengambilan data menggunakan Open Ended Questionnaire atau kuisioner terbuka. Kuisioner terbuka merupakan metode yang melibatkan partisipan untuk mengisi pertanyaan secara mandiri. Pemilihan metode ini supaya memberikan kebebasan kepada responden untuk menjawab pertanyaan. Kelebihan lainnya yaitu partisipan dapat menjawab pertanyaan secara mendalam dan memungkinkan jawaban yang original dari subjek penelitian. Beberapa poin yang menjadi pertanyaan terbuka meliputi Sikap Pemuda pada Lansia, Harapan Pemuda saat nanti menjadi lansia serta upaya mencapai harapan saat menjadi lansia.

\section{ANALISIS DATA}

Analisis Tema dan Kategorisasi

Analisis tema didasarkan pada asumsi, bahwa setiap budaya tidak lebih dari penjulahan adegan-adegan yang merupaka suatu sistem arti yang terintegrasi ke pola-pola yang lebih besar. (Firman, 2015). Analisis tema dan kategorisasi merupakan analisis yang menfokuskan pada tema dan kategorisasi penelitian ini.

Analisis Deskriptif

Pada penelitian ini digunakan analisis fenomenologi deskriptif. Fokus analisis ini yaitu penemuan fakta suatu fenomena proyeksi kesiapan pemuda menjadi lansia. Tujuan dalam menggunakan model analisis ini yaitu mengetahui lebih detil seberapa tinggi tingkat proyeksi kesiapan pemuda menjadi lansia.

\section{HASIL}

Penilaian dan Keyakinan Marawat Lansia

Berdasarkan hasil penelitian menunjukkan subjek merasa mampu 
untuk merawat lansia. Dari "pertanyaan yakinkah anda untuk merawat lansia?" menunjukkan bahwa 146 orang merasa yakin dalam merawat lansia, sebaliknya 61 orang merasa tidak mampu. Hal ini menunjukkan Sebagian besar merasa mampu merawat dan berinteraksi secara baik dengan lansia.

Alasan subjek merasa yakin bisa berinterasksi dan merawat lansia cukup beragam. Alasan-alasan ini terkategorisasi mulai dari merasa mempunyai kemampuan, telah berpengalaman, merada harus membalas budi pada orang tua dan merasa sudah menjadi tanggung jawab baginya. Alasan lain yang dikemukakan pada yang yakin adalah alasan yang berhubungan dengan ikatan kekeluargaan. alasan religius serta alasan proyeksi masa depan. Bagi subjek yang merasa tidak yakin beralasan kurang memiliki kompetensi, ada masalah mental (seperti tidak sabar, tidak telaten, jijik) serta merasa bisa mengandalkan pihak eksternal seperti panti jompo. Untuk lebih melihat distribusi lengkap dari alasan subjek bisa tergambar dalam tabel berikut.

\begin{tabular}{|c|c|}
\hline Alasan & Jumlah \\
\hline Pengalaman Positif & 37 \\
\hline Merasa Berkompeten & 34 \\
\hline Kewajiban & 26 \\
\hline Balas Budi & 15 \\
\hline Empati & 10 \\
\hline Tanggung Jawab & 7 \\
\hline Proyeksi & 4 \\
\hline Spiritual/Religious & 4 \\
\hline Relasi Keluarga & 4 \\
\hline Tidak Menjawab & 5 \\
\hline Total & 146 \\
\hline
\end{tabular}

Tabel 2

Distribusi Alasan Subjek yang Merasa Tidak Mampu

\begin{tabular}{lc}
\hline Alasan & Jumlah \\
\hline Kurang Berkompeten & 31 \\
Masalah Afeksi & 25 \\
Eksternal & 4 \\
Pengalaman Negatif & 1 \\
Tidak Menjawab & 2 \\
\hline Total & 61 \\
\hline
\end{tabular}

Dari tabel 1 dan tabel 2, terlihat bahwa hasil tabulasi silang keyakinan pemuda dengan alasan pemuda di dominasi dengan tingkat kompeten diri mereka dengan jumlah 29 responden yang yakin dan 4 responden sangat yakin akan kompetensi diri merawat lansia. Respon lain menetapkan bahwa ada beberapa alasan sebagai bentuk yakin responden dan jawaban tidak yakin didominasi dengan alasan yaitu kurang kompeten dalam merawat lansia. Perolehan dari tabulasi data tersebut sebanyak 27 responden tidak yakin dan 3 responden sangat tidak yakin atas kemampuan yang dimiliki dalam merawat lansia.

\section{Harapan Saat menjadi Lansia}

Dari pernyataan "harapan saat menjadi lansia?" menunjukkan bahwa ada 120 orang yang belum siap dan 104 orang yang merasa sudah siap dengan harapan yang mereka bayangkan. Data ini menunjukkan bahwa pemuda belum siap akan harapan yang mereka bayangkan pada saat usia lansia. 
Tabel 3

Bentuk Harapan Subjek yang Siap Menghadapi Masa Lansia

\begin{tabular}{lr}
\hline Bentuk Harapan & Jumlah \\
\hline Perasaan Bahagia & 32 \\
Keluarga Damai & 26 \\
Hidup sehat & 17 \\
Kecukupan Financial & 8 \\
Bermanfaat & 5 \\
Kasih sayang & 5 \\
Mandiri Fisik & 2 \\
Tidak menjawab & 2 \\
Sejahtera & 1 \\
\hline Total & 98 \\
\hline
\end{tabular}

Alasan yang diutarakan bervariasi seperti ingin hidup sehat, memiliki harta yang berlimpah atau mapan secara financial, kemudian ingin bermanfaat bagi lingkungan sekitar. Salah satu jawaban dari responden yaitu "Saya bisa berkontribusi di tempat dan masyarakat (saya menjadi penulis \& peneliti)". Jawaban ini termasuk dalam kategori bermanfaat di saat usia lansia. Alasan lain secara garis besar yaitu terkait keluarga, dimana pada kategori ini memiliki 44 orang. Kategori keluarga meliputi hidup tentram dengan cucu, anak, dan pasangan hidup.

Tabel 4

Bentuk Harapan Subjek yang Tidak Siap Menghadapi Masa Lansia

\begin{tabular}{lr}
\hline \multicolumn{1}{c}{ Bentuk Harapan } & Jumlah \\
\hline Keluarga Damai & 44 \\
Perasaan Bahagia & 31 \\
Hidup Sehat & 12 \\
Kasih Sayang & 10 \\
Mandiri Fisik & 8 \\
No Answer & 9 \\
Beribadah & 8 \\
Bermanfaat & 2 \\
Kecukupan Financial & 2 \\
\hline Total & 126 \\
\hline
\end{tabular}

Secara umum, ada kesamaan harapan baik mereka yang merasa siap menjadi manula maupun yang tidak. Keluarga Bahagia, hidup sehat serta perasaan tenang merupakan harapan pencapaian yang dihadapkan oleh mayoritas subjek.

Secara garis besar pada aitem harapan didominasi oleh kategori perasaan yang sudah siap. Sedangkan, kategori keluarga mendominasi pada item belum siap untuk menempuh usia lansia. Analisis menunjukkan bahwa kedua item saling berkaitan yaitu pemuda sudah memiliki harapan untuk usia lansia tetapi belum siap dalam langkah yang akan ditempuh.

\section{Upaya Menyiapkan Diri}

Selanjutnya, pertanyaan "upaya kesiapan diri di saat usia lansia?" memiliki dua kategori kesiapan dan tiga belas kategori besar. Responden yang menjawab belum siap sebanyak 120 orang dan 104 orang yang belum siap. Hal ini menunjukkan bahwa pemuda belum siap atas upaya yang dipersiapkan di saat menjadi lansia.

Tabel 5

\section{Upaya Memenuhi Harapan Menjadi} Lansia

\begin{tabular}{lr}
\hline Alasan & Jumlah \\
\hline Belajar & 46 \\
Memiliki Pekerjaan & 37 \\
Menjaga Kesehatan & 27 \\
Berkeluarga & 21 \\
Investasi & 18 \\
Belum ada upaya & 16 \\
Bersikap baik & 11 \\
lbadah & 8 \\
Perasaan & 8 \\
Cita-Cita & 5 \\
Memiliki Pengalaman & 4 \\
Tidak Menjawab & 23 \\
\hline Total & 224 \\
\hline
\end{tabular}


Alasan-alasan dari pertanyaan ini meliputi pemikiran realistis berupa memiliki pekerjaan menjadi jawaban paling dominan diantara pertanyaan lainnya. Selain itu, respon lain yaitu menyiapkan pendidikan yang tinggi untuk mencapai kebermanfaatan ilmu dan dasar financial pemuda. Salah satu respon terkait kategori belajar yaitu "Saya sedang berusaha untuk bekerja keras dengan belajar untuk menunjang masa depan. Dengan memiliki banyak ilmu, saya yakin dapat mencapai kebahagiaan dimasa yang akan datang". Secara tidak langsung, responden merasa bahwa pendidikan menjadi hal utama untuk masa tua nya dan dapat memberikan kebahagian pada dirinya.

Dalam tabel 5. menunjukkan bentuk upaya kesiapan menjadi lansia. yang menggambarkan bahwa kesiapan yang dominan diperoleh oleh kategori belajar. Kategori besar belajar terdiri dari kategorikategori kecil berupa melanjutkan pendidikan, belajar ilmu agama, bersikap rajin, dan belajar menjadi pribadi yang lebih baik. Kategori ini juga berkaitan dengan kategori pekerjaan.

Persiapan belajar yang ditempuh dengan pendidikan yang tinggi sebagai upaya untuk memiliki pekerjaan yang layak menurut responden. Selain itu, secara garis besar pemuda menyiapkan diri mereka dengan menjaga kesehatan sejak dini sehingga sesuai dengan harapan di usia lansia yaitu pemuda ingin mandiri sehingga tidak merepotkan keluarga. Tetapi, pada item belum siap kategori yang dominan terdapat pada kategori pekerjaan. Hal ini dapat di interpretasikan bahwa pemuda sudah memiliki gambaran untuk hidup di usia 60-an tahun tetapi merasa belum siap untuk menjadi lansia.

\section{PEMBAHASAN}

Hasil penelitian ini menunjukkan bahwa pemuda memiliki keyakinan yang tinggi untuk merawat lansia dengan dinyatakan berdasarkan kurang lebih sepuluh kategori yaitu balas budi, berkompeten, empati, kewajiban, pengalaman, proyeksi, spiritual/ religious, relasi keluarga, tanggung jawab, dan no answer dan unrelated. Pemuda bertanggung jawab atas lansia sebagai bentuk balas budi, kewajiban, dan sikap berkompeten yang dimiliki pemuda. Maka dari itu, pemuda harus bersikap baik kepada lansia dalam hal apapun, (Nugroho, 2020).

Namun, pemuda belum punya upaya kesiapan untuk menjadi lansia walaupun memiliki gambaran kesiapan kedepannya dikarenakan upaya menyiapkan diri di saat menjadi lansia membutuhkan proses yang panjang dan lama. Maka dari itu, banyak dari pemuda sudah memiliki gambaran kedepannya tetapi belum siap akan hal tersebut. Menurut, (Supriani et al., 2011) menyatakan bahwa salah satu fase dari lansia yaitu mulai melemahnya sistem imun tubuh. Hal ini memiliki korelasi dengan respon dari pemuda yang hampir di setiap pertanyaan menjawab berkaitan dengan kesehatan seperti kategori besar kesehatan dan kategori hidup sehat. Proyeksi yang dijalankan pemuda berupa menjaga kesehatan dengan mengatur pola makan hingg berolahraga. Upaya ini juga berkaitan dengan kategori mandiri sehingga tidak merepotkan keluarga untuk merawat.

Afrizal, (2018), menyatakan bahwa pada fase perkembangan lansia membutuhkan support sosial terutama kasih sayang oleh keluarga. Teori ini juga berkesinambungan dengan beberapa jawaban dari responden yang menjawab pada usia lansia membutuhkan kasih sayang dari orang terdekat seperti keluarga (anak, cucu, dan pasangan). Kasih sayang dibutuhkan karena tugas perkembangan lansia lebih memfokuskan kepada diri pribadi dari pada kehidupan orang lain maka dari itu lansia 
membutuhkan perhatian penuh dari keluarganya. Keyakinan pemuda dalam merawat lansia juga dikarenakan alasan meliputi balas budi dan karma. Perasaan ingin berbuat baik kepada lansia sebagai bentuk ketakutan pemuda belum bisa balas budi dan karma yang akan terjadi mendatang.

Pemuda beranggapan bahwa harapan di saat usia lansia dapat dilakukan dengan hobi, bertemu dengan rekan sebaya, keluarga, dan bermanfaat untuk masyarakat. Beberapa kategori ini juga relevan dengan pandangan (Nugroho, 2020) yang menyatakan bahwa kekhawatiran berlebihan dari keluarga menyebabkan lansia tertekan karena terisolasi. Tetapi, penelitian sebelumnya memaparkan bahwa pemuda tidak menyetujui lansia untuk bekerja dan belajar di masa tuanya. Sama halnya dengan hasil penelitian ini yang menunjukkan hasil kategori dari jawaban responden yaitu tidak terdapat kategori belajar dan bekerja di saat usia lansia.

Dapat disimpulkan bahwa pemuda yakin dalam merawat lansia dan memiliki harapan di saat usia lansia dengan gambaran yang bervariasi. Namun, pemuda belum siap atas harapan dan upaya menyiapkan diri di saat usia lansia. $\mathrm{Hal}$ ini dikarenakan proyeksi pemuda menjadi lansia membutuhkan proses yang panjang dan lama. Maka dari itu, upaya menyiapkan diri di saat menjadi lansia di dominasi dengan kategori belajar dan memiliki pengalaman. Solusi untuk pemuda dalam upaya menyiapkan diri di saat menjadi lansia sudah hampir sesuai dengan jawaban responden yaitu dapat menekuni pendidikan yang ditempuh sekarang dengan tekun dan gigih, selain itu menjaga pola maka untuk hidup sehat dan menambah skill di saat muda maka akan dapat menikmati di hari tua.
Memahami kesiapan pemuda dalam berinteraksi Bersama lansia, serta harapan-harapan pemuda saat nanti menjadi lansia menjadi modal dalam mencapai kebahagian dan kelansungan sebuah generasi. Sebuah generasi dalam hal ini pemuda jika siap menghadapi masa tuanya dia akan bisa menyiapkan diri dan menyiapkan generasi selanjutnya (anakanak). Upaya mengedukasi baik secara formal maupun non formal dengan pendekatan yang lebih rasional menjadi keharusan. Mempromosikan kesaiapan menghadapi lansia tidak cukup hanya dengan pendekatan normative, tapi juga perlu upaya sistematik baik dari sisi personal, keluarga maupun komunitas.

Munculnya banyak desa atau kewasan ramah lansia tidak hanya berfokus pada pemberian pelayanan pada lansia. Lebih dari itu membangun relasi antar generasi (Kekek/nenek, anak dan cucu) menjadi penting dalam mencapai kebahagiaan di masa lansia dalam keluarga.

\section{PENUTUP}

Berdasarkan hasil penelitian di atas dapat disimpulkan bahwa secara garis besar pemuda belum siap untuk menjadi lansia walaupun sudah memiliki gambaran upaya menyiapkan menjadi lansia. Pemuda merasa yakin dapat merawat lansia dengan alasan paling banyak yaitu kategori berkompeten dan tidak yakin dengan alasan kurang kompeten secara lahir dan batin. Kemudian, harapan yang paling banyak terdapat di kategori perasaan, dimana pemuda ingin merasakan hidup tentram, damai, tenang bersama keluarga dan mapan financial.

Penelitian ini memproyeksikan pemuda menjadi lansia dengan memaparkan bentuk upaya kesiapan pemuda di saat usia sekitar kurang lebih 60 tahun. Maka dari itu, penelitian ini merupakan penelitian sebelumya yang dilakukan untuk 
mengetahui persepsi pemuda terhadap lansia dan pada penelitian ini dipaparkan lebih jauh tentang proyeksi pemuda menjadi lansia. pertanyaan terbuka yang diberikan kepada responden dan analisis tabulasi silang yang dilakukan semoga dapat memberikan data yang valid serta menjadi contoh untuk dilakukannya penelitian-penelitian selanjutnya secara mendalam. Selain itu, semoga penelitian ini dapat memberikan sumbangan terhadap perkembangan ilmu psikologi dan juga kebermanfaatan bagi kemajuan dunia pendidikan.

\section{DAFTAR PUSTAKA}

Afrizal, A. (2018). Permasalahan Yang Dialami Lansia Dalam Menyesuaikan Diri Terhadap Penguasaan TugasTugas Perkembangannya. Islamic Counseling: Jurnal Bimbingan Konseling Islam, 2(2), 91. https://doi.org/10.29240/jbk.v2i2.462

Ekowati, C. R. (2011). Penyesuaian diri terhadap hilangnya pasangan hidup pada lansia. Jurnal Keperawatan Lansia, 1-138.

Firman. (2015). Analisis Data Dalam Kualitatif. Article, 4, 1-13.

Hurlock, E. B. (1991). Masa - Masa Remaja. In Psikologi Perkembangan (pp. 205-243).

Indarwati, R. (2020). Lindungi Lansia dari Covid-19. Jurnal Keperawatan Komunitas, 5(1), 2020.

Indonesia, U. P. (2016). Faktor-Faktor Yang Mendasari Stres Pada Lansia.

Jurnal Penelitian Pendidikan UPI, 16(1), 124302.

Karomah, N. N. (2015). Hubungan Tingkat Spiritual Dengan Kecemasan Terhadap Kematian Pada Lansia Yang Memiliki Penyakit Kronis.

Misnaniarti, M. (2017). Situation Analysis of Elderly People and Efforts To
Improve Social Welfare in Indonesia. Jurnal IImu Kesehatan Masyarakat, 8(2), $\quad$ 67-73. https://doi.org/10.26553/jikm.2017.8.2.6 7-73

Naafs, S., \& White, B. (2012). Generasi Antara: $\mathrm{Re} \mathrm{fl}$ eksi tentang Studi Pemuda Indonesia * Pemuda sebagai Generasi Orang muda adalah aktor kunci dalam. I(2), 89-106. https://journal.ugm.ac.id/jurnalpemuda/a rticle/viewFile/32063/19387

Nugroho, A. (2020). Persepsi Anak Muda Terhadap Keberadaan Lansia Di Indonesia. Journal of Urban Sociology, 2(2), 44. https://doi.org/10.30742/jus.v2i2.996

Ratnawulan, T. (2018). Perkembangan dan Tahapan Penting dalam Perkembangan. Journal of Special Education, IV(01), 65-74.

Siagian, T. H. (2020). Corona Dengan Discourse Network Analysis. Jurnal Kebijakan Kesehatan Indonesia, 09(02), 98-106.

Wiyono, J., Sahar, J., \& Wiarsih, W. (2008). Pengalaman Keluarga Merawat Lansia dengan Tingkat Ketergantungan Tinggi di Rumah, Kota Malang, Jawa Timur: Studi Fenomenologi. Jurnal Keperawatan Indonesia, 12(2), 76-83. https://doi.org/10.7454/jki.v12i2.204

Yuhono, P. (2017). Gambaran peran keluarga dalam merawat lansia dengan ketergantungan di desa pabelan. Skripsi, $1-17$. http://eprints.ums.ac.id/51710/1/Naskah Publikasi.pdf

https://www.psychiatrictimes.com/view/gro wing-crisis-mental-health-amongnations-elderly

https://www.mentalhelp.net/blogs/intergene rational-programs-keeping-seniorsyoung-making--youth-wiser/

https://www.solopos.com/kisah-sedih-ibuasal-magelang-diabaikan-anak-dikirimke-panti-jompo-1184172 